\title{
COMPARISON BETWEEN THE RESULTS OF THE PILE BEARING CAPACITY ANALYSIS BASED ON EMPIRICAL METHOD AND FINITE ELEMENT METHOD USING THE RESULTS OF DYNAMIC ANALYSIS ON THE FIELD
}

\author{
Michael Antonie Prayogo ${ }^{a}$, Herman Wahyudi ${ }^{*}$, Indrasurya B. Mochtar ${ }^{*}$
}

\begin{abstract}
There are many methods for calculating the bearing capacity of a pile foundation. The problem is finding the most representative method for analysis dynamic load testing (PDA) results in the field. This study only covers the areas of West Surabaya and North Surabaya. The method used to analyze the bearing capacity of the pile foundation in this study is the empirical method, namely the Schmertmann, Meyerhof, and L. Decourt method and the finite element method (FEM.). This research only for calculating the bearing capacity of precast pile foundations. The initial stage of the research was to collect soil survey data in the form of N-SPT boring logs and PDA test results in the area. Then the calculation analysis is carried out using the empirical method and FEM, which will be compared with the PDA results. FEM analysis uses dynamic load with piledriving modelling, which is similar to PDA testing. After comparison, the researchers find some ratios for each calculation method and results of PDAs in the field of study. This study indicates that the most representative method for PDA results in West Surabaya is the Meyerhof method. For the North Surabaya area, these methods have not shown expected results of PDA results in the field
\end{abstract}

Keywords: Pile dynamic analysis, dynamic load test, pile bearing capacity, West Surabaya, North Surabaya

\section{INTRODUCTION}

There are many ways to calculate the bearing capacity of the pile foundation. Each method has its characteristics and suitability depending on the constraints and parameters used. However, most of the methods used to result from application or research in other countries whose soil patterns may not be the same as those in Indonesia [1]. In general, to get the actual pile bearing capacity in the field, a full-scale load test is carried out (Static Load Test, SLT) or using dynamic load testing (Dynamic Load Test, DLT). Most geotechnical experts use the empirical method and the Finite Element Method (FEM) to estimating the bearing capacity of the pile. Each of these methods will produce different results, and the results, compared with the test results with Pile Dynamic Analysis (PDA), are not always consistent.

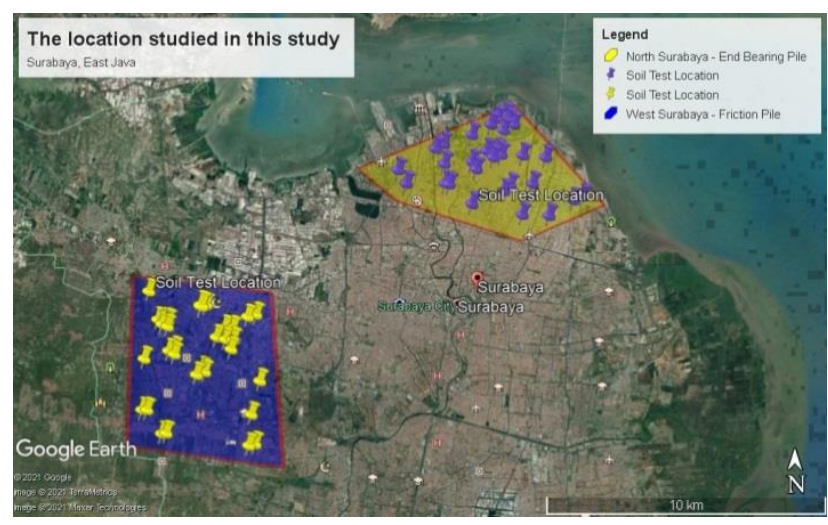

Figure 1 Location for Collecting Data

\section{RESEARCH SIGNIFICANCE}

This paper analyses which method is the most representative of the PDA test results by comparing the

${ }^{a}$ Lecturer in the Civil Engineering Department, Institut Teknologi Sepuluh Nopember, ITS Campus, Sukolilo, Surabaya 6011, Indonesia. Corresponding author email address: piscesa@ce.its.ac.id empirical method calculation results with the PDA test results on the field. The comparison results will produce ratios as a representative indicator of the method to the PDA results. If the balance is between the Analytical method and the PDA result is 0.75 to 1.25 , conclusively, the analytical method is representative of PDA. So far, there has been no research aimed at finding out which method of the estimated bearing capacity of piles is more suitable for the city of Surabaya based on variations in soil conditions in it, which can be compared with the PDA results. For more details, the locations reviewed in this study can be seen in Figure 1.

\section{METHODOLOGY}

In the early stages of the research, Researchers collected all required data collection in the form of soil investigation data, laboratory test results to determine mechanicalphysical properties, and data from PDA and SLT testing in West Surabaya and North Surabaya areas. The calculation of the bearing capacity of precast pile foundations using empirical methods consisting of L. Decourt, Schmertmann, and Meyerhof [2].It was also using FEM to calculate the bearing capacity using soil parameters from soil investigations in the field and the laboratory test results in West Surabaya and North Surabaya.

\section{A. DATA COLLECTION OF SOIL INVESTIGATION}

Soil investigation data were taken from each field study and its surroundings as many as 30 points. From all the data collected from the soil survey, a statistical analysis was carried out, and the results were shown in Table 1.

\section{B. DATA COLLECTION OF SLT AND PDA TEST RESULTS}

A comparison is made with the SLT test results to find out that these methods are reliable. The analysis of the bearing capacity calculation for a spun pile foundation with a crosssection size of $45 \mathrm{~cm}$ at a depth of $31 \mathrm{~m}$ in the West 
Surabaya area. The total number of PDA test results collected for the West Surabaya and North Surabaya areas is around 40 points for each location with varying pile sizes and depths attached in Table 3 and Table 4.

Table 1 Results of Statistical Analysis in West Surabaya and North Surabaya

\begin{tabular}{ccccc}
\hline $\begin{array}{c}\text { Depth } \\
(\mathrm{m})\end{array}$ & $\begin{array}{c}\text { West Surabaya } \\
\text { N-SPT }\end{array}$ & Soil Type & $\begin{array}{c}\text { North Surabaya } \\
\text { N-SPT }\end{array}$ & Soil Type \\
\hline 1.25 & 1 & Clay & 1 & Clay \\
3.25 & 1 & Clay & 1 & Clay \\
5.25 & 3 & Clay & 1 & Clay \\
7.25 & 4 & Clay & 1 & Clay \\
9.25 & 1 & Clay & 1 & Clay \\
11.25 & 4 & Clay & 1 & Clay \\
13.25 & 6 & Clay & 1 & Clay \\
15.25 & 8 & Clay & 2 & Clay \\
17.25 & 8 & Clay & 5 & Clay \\
19.25 & 10 & Clay & 6 & Clay \\
21.25 & 9 & Clay & 9 & Clay \\
23.25 & 12 & Clay & 13 & Sand \\
25.25 & 10 & Clay & 20 & Sand \\
27.25 & 12 & Clay & 23 & Sand \\
29.25 & 14 & Clay & 36 & Sand \\
31.25 & 13 & Clay & 29 & Sand \\
33.25 & 12 & Clay & 27 & Sand \\
35.25 & 14 & Clay & 26 & Sand \\
\hline
\end{tabular}

\section{ANALYSIS AND DISCUSSIONS}

As explained in the previous chapter regarding the comparison of the empirical method and the finite element method with the SLT test results, an analysis of the bearing capacity calculation was carried out for a spun pile foundation with a cross-sectional size of $45 \mathrm{~cm}$ at a depth of $31 \mathrm{~m}$ in the West Surabaya area. SLT testing has been carried out on these pile conditions and produces a bearing capacity of 392 tonnes using the Davisson method by reading the Load vs Settlement curve. The researcher then analyzed calculations using the method of L. Decourt, Schmertmann, and Meyerhof. [2] and the Finite Element Method.

A. COMPARISON RESULT of Empirical Methods and FEM with SLT Test Results IN WEST SURABAYA

Comparison result of these methods with the SLT test is in Table 2. From these results, the researcher concluded the most suitable is Meyerhof. The other method is still reliable for the SLT results with an average ratio of 1.25 , which can be continued to the following analysis stage.

Table 2 The results of Comparison of the Empirical Methods and FEM against SLT in West Surabaya

\begin{tabular}{cc}
\hline $\begin{array}{c}\text { Analytical Method } \\
\text { Method }\end{array}$ & Q-ult ratio against PDA \\
\hline Schmertmann (1967) & 1.37 \\
Meyerhof (1976) & 1.02 \\
L. Decourt (1996) & 1.57 \\
FEM & 1.05 \\
\hline
\end{tabular}

\section{B. COMPARISON RESULTS OF EMPIRICAL METHODS WITH PDA TEST RESULTS IN WEST SURABAYA}

After analyzing using the empirical method and FEM using Dynamic load, the researcher compared the results with the PDA in Table 2. From the results of the average ratio from 41 piles in West Surabaya between Qp and Qs, it can be concluded that the most representative empirical method with the dominant clay soil conditions in West Surabaya is the Meyerhof method with a Qp ratio of 0.91 and Qs 0.71 . Table 4 shows the Qp ratio for the two methods, namely L. Decourt and Schmertmann, which is 0.23 and 0.39. It is because both methods use a coefficient for a different soil. The Meyerhof method use the same coefficient for all soil types for end-bearing analysis. From this discussion, it can also be estimated that for the soil conditions in West Surabaya, Qp and Qs in the PDA results have been fully mobilized. It can be seen that the results of the PDA are more excellent than the results of the empirical calculation methods, both Qp and Qs.

Because all empirical methods are analyzed based on ultimate capacity, the PDA test results are not estimated to have reached the ultimate bearing capacity because it only produces the mobilized carrying capacity of the given hammer energy. Meanwhile, according to Santoso's [3] research, which also examines the condition of the pile foundation in areas with clay-dominant soil, it gives a ratio of 0.98 for the L. Decourt, Meyerhof, and Schmertmann methods which are in the very high category. In this study, the L. Decourt method provides a ratio of 0.51 , the Schmertmann method of 0.53, and the Meyerhof method of 0.81 for the West Surabaya area, predominantly clay. This conclusion can occur due to variations in the crosssectional size, length of the pile, and the number of pile foundations being analyzed.

\section{COMPARISON RESULTS OF EMPIRICAL METHODS WITH PDA TEST RESULTS IN NORTH SURABAYA}

After analyzing using the empirical method and FEM using Dynamic load, the results of the analysis are compared with the PDA test results in Table 6.

From these results, the researcher concluded that there was no sufficiently representative method for PDA results in North Surabaya. However, the method with the closest Qp ratio number to 1 is the Meyerhof method. Whereas for the method with the Qs ratio number most relative to 1 is the method is L. Decourt.

When compared with Zakahfi's research [4] which states that the L. Decourt method has a high correlation with PDA results with a ratio of 1.34 , while in this study, the balance for the L. Decourt method in West Surabaya is 0.51 and in the north part of Surabaya is 1.45 . The number of piles studied in Zakahfi's study is only based on one case study area. In this study, the number of piles analyzed was more varied across cross-sectional sizes and lengths of piles and different soil conditions. In this comparative analysis, it can be seen that most of the empirical methods used produce the ratio of the linear approach Qs which is 
Table 3 PDA Test Results in West Surabaya

\begin{tabular}{|c|c|c|c|c|c|c|c|c|c|c|c|c|c|}
\hline No & $\begin{array}{l}\text { Pile } \\
\text { Type }\end{array}$ & $\begin{array}{l}\text { Cross- } \\
\text { section } \\
(\mathrm{cm})\end{array}$ & $\begin{array}{c}\text { Depth } \\
\text { (m) }\end{array}$ & $\begin{array}{l}\mathrm{Qp} \\
\text { (ton) }\end{array}$ & $\begin{array}{l}\text { Qs } \\
\text { (ton) }\end{array}$ & $\begin{array}{c}\mathrm{RMX} \\
\text { (ton) }\end{array}$ & No & $\begin{array}{l}\text { Pile } \\
\text { Type }\end{array}$ & $\begin{array}{l}\text { Cross } \\
\text { section } \\
(\mathrm{cm})\end{array}$ & $\begin{array}{l}\text { Depth } \\
\text { (m) }\end{array}$ & $\begin{array}{c}\mathrm{Qp} \\
\text { (ton) }\end{array}$ & $\begin{array}{c}\text { Qs } \\
\text { (ton) }\end{array}$ & $\begin{array}{c}\text { RMX } \\
\text { (ton) }\end{array}$ \\
\hline 1 & Square pile & 25 & 10 & 44 & 76 & 120 & 22 & Spun pile & 50 & 28 & 84 & 269 & 353 \\
\hline 2 & Square pile & 25 & 13 & 46 & 62 & 108 & 23 & Spun pile & 50 & 28 & 145 & 239 & 384 \\
\hline 3 & Square pile & 25 & 13 & 49 & 77 & 126 & 24 & Spun pile & 50 & 28 & 61 & 251 & 313 \\
\hline 4 & Square pile & 25 & 15 & 49 & 77 & 126 & 25 & Spun pile & 50 & 28 & 65 & 310 & 376 \\
\hline 5 & Square pile & 25 & 17 & 27 & 83 & 111 & 26 & Spun pile & 50 & 28 & 71 & 277 & 347 \\
\hline 6 & Square pile & 25 & 18 & 23 & 90 & 113 & 27 & Spun pile & 50 & 28 & 105 & 165 & 270 \\
\hline 7 & Square pile & 25 & 18 & 24 & 74 & 97 & 28 & Spun pile & 50 & 23 & 121 & 226 & 347 \\
\hline 8 & Square pile & 25 & 18 & 25 & 70 & 94 & 29 & Spun pile & 50 & 28 & 105 & 253 & 358 \\
\hline 9 & Square pile & 25 & 20 & 34 & 36 & 70 & 30 & Spun pile & 50 & 28 & 47 & 139 & 186 \\
\hline 10 & Square pile & 25 & 21 & 18 & 52 & 70 & 31 & Spun pile & 50 & 28 & 47 & 320 & 367 \\
\hline 11 & Square pile & 25 & 21 & 18 & 52 & 70 & 32 & Spun pile & 50 & 28 & 112 & 202 & 314 \\
\hline 12 & Square pile & 35 & 25 & 69 & 177 & 245 & 33 & Spun pile & 50 & 29 & 81 & 315 & 396 \\
\hline 13 & Square pile & 35 & 28 & 18 & 135 & 154 & 34 & Spun pile & 50 & 28 & 58 & 205 & 263 \\
\hline 14 & Square pile & 35 & 28 & 22 & 132 & 154 & 35 & Spun pile & 50 & 29 & 92 & 287 & 378 \\
\hline 15 & Square pile & 35 & 28 & 20 & 132 & 153 & 36 & Spun pile & 50 & 29 & 13 & 322 & 335 \\
\hline 16 & Square pile & 35 & 29 & 98 & 261 & 359 & 37 & Spun pile & 50 & 25 & 93 & 263 & 355 \\
\hline 17 & Square pile & 35 & 30 & 73 & 182 & 255 & 38 & Spun pile & 50 & 21 & 78 & 253 & 331 \\
\hline 18 & Spun pile & 45 & 29 & 22 & 255 & 276 & 39 & Spun pile & 50 & 24 & 96 & 219 & 314 \\
\hline 19 & Square pile & 50 & 28 & 109 & 248 & 357 & 40 & Spun pile & 50 & 22 & 36 & 265 & 301 \\
\hline 20 & Spun pile & 50 & 28 & 67 & 293 & 360 & 41 & Spun pile & 50 & 28 & 46 & 169 & 215 \\
\hline 21 & Spun pile & 50 & 28 & 94 & 244 & 338 & & & & & & & \\
\hline
\end{tabular}

Note: RMX is the maximum total static resistance of hammer blow energy at PDA testing.

Table 4 PDA Test Results in North Surabaya

\begin{tabular}{|c|c|c|c|c|c|c|c|c|c|c|c|c|c|}
\hline No & $\begin{array}{l}\text { Pile } \\
\text { Type }\end{array}$ & $\begin{array}{l}\text { Cross- } \\
\text { section } \\
(\mathrm{cm})\end{array}$ & $\begin{array}{l}\text { Depth } \\
\text { (m) }\end{array}$ & $\begin{array}{c}\mathrm{Qp} \\
\text { (ton) }\end{array}$ & $\begin{array}{l}\text { Qs } \\
\text { (ton) }\end{array}$ & $\begin{array}{c}\mathrm{RMX} \\
\text { (ton) }\end{array}$ & No & $\begin{array}{l}\text { Pile } \\
\text { Type }\end{array}$ & $\begin{array}{l}\text { Cross } \\
\text { section } \\
(\mathrm{cm}) \\
\end{array}$ & $\begin{array}{c}\text { Depth } \\
\text { (m) }\end{array}$ & $\begin{array}{c}\mathrm{Qp} \\
\text { (ton) }\end{array}$ & $\begin{array}{l}\text { Qs } \\
\text { (ton) }\end{array}$ & $\begin{array}{c}\mathrm{RMX} \\
\text { (ton) }\end{array}$ \\
\hline 1 & Square pile & 25 & 23 & 29 & 70 & 99 & 24 & Spun Pile & 35 & 27 & 56 & 153 & 209 \\
\hline 2 & Square pile & 25 & 23 & 38 & 72 & 110 & 25 & Square pile & 35 & 28 & 38 & 126 & 163 \\
\hline 3 & Square pile & 25 & 23 & 16 & 72 & 88 & 26 & Spun Pile & 35 & 29 & 50 & 136 & 185 \\
\hline 4 & Square pile & 25 & 26 & 34 & 105 & 139 & 27 & Spun pile & 35 & 29 & 49 & 83 & 132 \\
\hline 5 & Square pile & 25 & 26 & 83 & 123 & 206 & 28 & Square pile & 35 & 29 & 78 & 95 & 173 \\
\hline 6 & Square pile & 25 & 26 & 88 & 118 & 206 & 29 & Square pile & 35 & 29 & 28 & 39 & 67 \\
\hline 7 & Square pile & 25 & 26 & 98 & 122 & 220 & 30 & Spun pile & 35 & 33 & 58 & 134 & 192 \\
\hline 8 & Square pile & 25 & 26 & 40 & 68 & 108 & 31 & Spun Pile & 50 & 25 & 39 & 204 & 243 \\
\hline 9 & Square pile & 25 & 26 & 26 & 67 & 93 & 32 & Spun Pile & 50 & 25 & 58 & 243 & 301 \\
\hline 10 & Square pile & 25 & 30 & 65 & 111 & 176 & 33 & Spun Pile & 50 & 25 & 76 & 127 & 203 \\
\hline 11 & Square pile & 25 & 32 & 42 & 149 & 191 & 34 & Spun Pile & 50 & 26 & 115 & 170 & 285 \\
\hline 12 & Square pile & 25 & 33 & 36 & 190 & 225 & 35 & Spun Pile & 50 & 28 & 197 & 259 & 456 \\
\hline 13 & Square pile & 25 & 33.5 & 63 & 142 & 205 & 36 & Spun Pile & 50 & 28 & 187 & 242 & 429 \\
\hline 14 & Square pile & 25 & 33.5 & 44 & 161 & 204 & 37 & Square pile & 50 & 30 & 98 & 343 & 441 \\
\hline 15 & Square pile & 25 & 33.5 & 60 & 165 & 224 & 38 & Square pile & 50 & 30 & 89 & 269 & 358 \\
\hline 16 & Square pile & 25 & 33.5 & 68 & 136 & 204 & 39 & Square pile & 50 & 30 & 110 & 285 & 395 \\
\hline 17 & Square pile & 25 & 33.5 & 92 & 115 & 207 & 40 & Square pile & 50 & 30 & 73 & 330 & 403 \\
\hline 18 & Square pile & 25 & 33.5 & 88 & 132 & 220 & 41 & Square pile & 50 & 30 & 93 & 305 & 398 \\
\hline 19 & Spun Pile & 30 & 24 & 9 & 89 & 98 & 42 & Spun Pile & 60 & 30 & 48 & 137 & 185 \\
\hline 20 & Spun Pile & 30 & 24 & 14 & 81 & 96 & 43 & Spun Pile & 60 & 30 & 41 & 144 & 184 \\
\hline 21 & Square pile & 30 & 30 & 16 & 55 & 71 & 44 & Spun Pile & 60 & 30 & 33 & 180 & 212 \\
\hline 22 & Square pile & 30 & 30 & 14 & 94 & 107 & 45 & Spun Pile & 60 & 25 & 78 & 165 & 243 \\
\hline 23 & Square pile & 30 & 30 & 18 & 86 & 105 & & & & & & & \\
\hline
\end{tabular}

Note: RMX is the maximum total static resistance of hammer blow energy at PDA testing.

Table 5 The results of Comparison of the Empirical

Table 6 The results of Comparison of the Empirical Method against PDA in West Surabaya Method against PDA in North Surabaya

\begin{tabular}{|c|c|c|c|c|c|}
\hline $\begin{array}{c}\text { Empirical } \\
\text { Method }\end{array}$ & $\begin{array}{c}\text { Average } \mathrm{Qp} \text { ratio } \\
\text { against PDA }\end{array}$ & $\begin{array}{c}\text { Average Qs ratio } \\
\text { against PDA }\end{array}$ & $\begin{array}{c}\text { Empirical } \\
\text { Method }\end{array}$ & $\begin{array}{c}\text { Average Qp ratio } \\
\text { against PDA }\end{array}$ & $\begin{array}{c}\text { Average Qs ratio } \\
\text { against PDA }\end{array}$ \\
\hline Schmertmann (1967) & 0.23 & 0.82 & Schmertmann (1967) & 1.67 & 0.45 \\
\hline Meyerhof (1976) & 0.91 & 0.71 & Meyerhof (1976) & 1.33 & 0.42 \\
\hline L. Decourt (1996) & 0.39 & 0.66 & L. Decourt (1996) & 2.10 & 0.79 \\
\hline
\end{tabular}

smaller on average than the PDA results. It happens because when testing the PDA Qs on the pile foundation, it is first mobilized from the hammer load given, and the amount of energy and force exerted on the pile can make Qp at the end of the pile be mobilized or not. It also affects 
the length of the pile foundation, where the longer the pile foundation, the greater the mobile Qs compared to the Qp.

It occurs at the end-bearing pile, where it can be seen in the tests in North Surabaya and its surroundings because the Qp of the analysis results is greater than the Qp of the PDA. For the friction pile in West Surabaya, the Qp analysis result is smaller than the PDA result. The analysis method gives too small a coefficient for clays, especially clays with stiff consistency such as those in West Surabaya. The mobilized from the energy supplied from the hammer during the PDA test. In testing PDAs with soil conditions in North Surabaya, it requires enormous hammer energy to produce enough power to mobilize Qp and Qs so that their value on PDA testing are the same as the results of empirical method calculations.

\section{COMPARISON RESULT FEM USING DYNAMIC LOAD WITH PDA TEST RESULTS IN WEST SURABAYA AND NORTH SURABAYA}

From the comparison of RMX between FEM and PDA, it can be seen that West Surabaya produces a better correlation number than in North Surabaya. However, RMX is only the Maximum Static Resistance that the pile foundation receives from the minimum energy applied. So the result would not produce Qp and Qs without analysis using CAPWAP. From the comparison of RMX between FEM and PDA in West Surabaya, its ratio is 1.1 and it can be concluded that the FEM analysis with dynamic loads on the dominant clay soil and friction type pile is close to the PDA results. This conclusion can be used as a backanalysis of the results of the PDAs that have been obtained. Meanwhile, in the soil conditions in North Surabaya, the FEM method is quite representative. However, further analysis is needed because the PDA results in North Surabaya are not expected to be fully mobilized.

The ratio of the FEM analysis with Dynamic Load cannot be compared with the balance from the Empirical method. It is because the ratio obtained from the two methods has two different results. RMX received from FEM cannot produce Qp and Qs without CAPWAP on the pile foundation, which is different from the results of the empirical method, which can produce Qp and Qs as a whole.

\section{CONCLUSIONS}

From the data and analysis in the previous chapter, it can be concluded that the comparison between the empirical method and the FEM on the PDA results shows that not all methods are reliable with the PDA results.

The most representative empirical method for analyzing the bearing capacity of friction pile foundations with medium to stiff clay prevailing soil conditions such as in the West part of Surabaya and its surroundings to PDA results is the Meyerhof method with the average ratio Qp and Qs is 0.91 and 0.71 . The ratio of the Meyerhof method is the closest ratio to 1 compared to the L. Decourt and Schmertmann method with its Qp ratio of 0.39 and 0.23.

There is no empirical method that is most representative for analyzing the bearing capacity in the area, such as in the North part of Surabaya and its surroundings on the PDA results. This can be seen from the Qp ratio of L. Decourt, Schmertmann, and Meyerhof are
$2.10,1.66$, and 1.33. It happens because, for soil conditions such as in North Surabaya, the value of Qp from PDA does not necessarily $=$ Qp-ultimate analyzed using empirical methods. It is thought to occur because the energy from the hammer at the time of testing was not large enough to ultimately mobilize the end-bearing pile foundation in soil conditions such as North Surabaya.

The FEM method with Dynamic Load on pile foundations with PDA results gives the most representative results with a ratio of 1.1 in West Surabaya soil conditions and a ratio of 1.3 in soil conditions in North Surabaya on the comparison of RMX results.

\section{REFERENCES}

[1] Afriyanto, A., and Sipil, J. T. Macam Metode Pada Proyek Apartemen the Frontage Surabaya. 2017

[2] A. Sridharan and Y. Gurtug, "Compressibility characteristics of soils," Geotechnical and Geological Engineering, vol. 23, no. 5, pp. 615-634, 2005, doi: 10.1007/s10706-004-9112-2.

[3] H. T. Santoso and J. Hartono, “Analisis Perbandingan Daya Dukung Pondasi Tiang Pancang Berdasar Hasil Uji Spt Dan Pengujian Dinamis," Jurnal Riset Rekayasa Sipil, vol. 4, no. 1, p. 30, 2020, doi: 10.20961/jrrs.v4i1.44635.

[4] A. T. Zakahfi and R. Kusumawardani, "Perbandingan Analisa Daya Dukung Tiang Pancang Menggunakan Metode Perhitungan L. Decourt Dan Tes Pda," Teknika, vol. 13, no. 1, p. 1, 2018, doi: 10.26623/teknika.v13i1.724. 